\title{
The Medieval Globe
}

Volume 1

Number 1 Pandemic Disease in the Medieval

World: Rethinking the Black Death

Article 3

2014

\section{Editor's Introduction to Pandemic Disease in the Medieval World: Rethinking the Black Death}

Monica H. Green

Arizona State University, monica.green@asu.edu

Follow this and additional works at: https://scholarworks.wmich.edu/tmg

Part of the Ancient, Medieval, Renaissance and Baroque Art and Architecture Commons, Classics Commons, Comparative and Foreign Law Commons, Comparative Literature Commons, Comparative Methodologies and Theories Commons, Comparative Philosophy Commons, Medieval History Commons, Medieval Studies Commons, and the Theatre History Commons

\section{Recommended Citation}

Green, Monica H. (2014) "Editor's Introduction to Pandemic Disease in the Medieval World: Rethinking the Black Death," The Medieval Globe: Vol. 1 : No. 1 , Article 3.

Available at: https://scholarworks.wmich.edu/tmg/vol1/iss1/3

This Article is brought to you for free and open access by the Medieval Institute Publications at ScholarWorks at WMU. It has been accepted for inclusion in The Medieval Globe by an authorized editor of ScholarWorks at WMU.

For more information, please contact wmuscholarworks@wmich.edu.






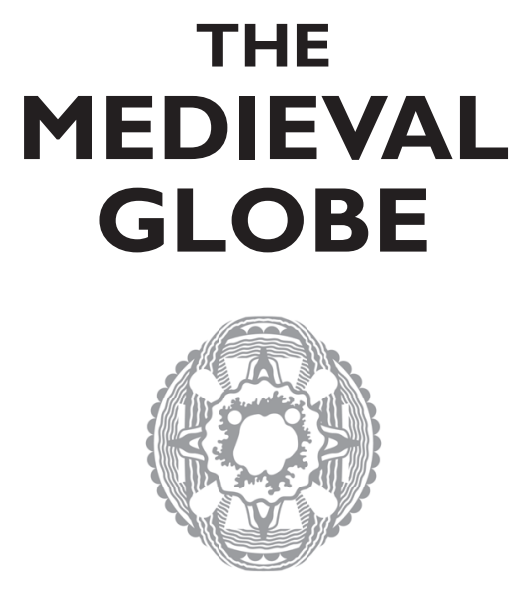

Volume 1 | 2014

\section{INAUGURAL DOUBLE ISSUE \\ PANDEMIC DISEASE IN THE MEDIEVAL WORLD}

RETHINKING THE BLACK DEATH

Edited by MONICA H. GREEN

ARCMedieval press 
Immediate Open Access publication of this special issue was made possible by the generous support of the World History Center at the University of Pittsburgh.

\author{
Copyeditor \\ Shannon Cunningham \\ Editorial Assistant \\ Ann Hubert \\ Page design and typesetting \\ Martine Maguire-Weltecke
}

\title{
Library of Congress Cataloging in Publication Data
}

A catalog record for this book is available from the Library of Congress

\section{(C) 2014 Arc Medieval Press, Kalamazoo and Bradford}

This work is licensed under a Creative Commons Attribution-

NonCommercial-NoDerivatives 4.0 International Licence.

The authors assert their moral right to be identified as the authors of their part of this work.

Permission to use brief excerpts from this work in scholarly and educational works is hereby granted provided that the source is acknowledged. Any use of material in this work that is an exception or limitation covered by Article 5 of the European Union's Copyright Directive (2001/29/EC) or would be determined to be "fair use" under Section 107 of the U.S. Copyright Act September 2010 Page 2 or that satisfies the conditions specified in Section 108 of the U.S. Copyright Act (17 USC §108, as revised by P.L. 94-553) does not require the Publisher's permission.

ISBN 978-1-942401-04-9

www.arc-humanities.org 


\section{CONTENTS}



Introducing The Medieval Globe

Carol Symes 1

Editor's Introduction to Pandemic Disease in the Medieval World: Rethinking the Black Death

Monica H. Green

Taking "Pandemic" Seriously: Making the Black Death Global

Monica H. Green

The Black Death and Its Consequences for the Jewish

Community in Tàrrega: Lessons from History and Archeology

Anna Colet, Josep Xavier Muntané i Santiveri, Jordi Ruíz Ventura,

Oriol Saula, M. Eulàlia Subirà de Galdàcano, and Clara Jáuregui .

The Anthropology of Plague:

Insights from Bioarcheological Analyses of Epidemic Cemeteries

Sharon N. DeWitte

Plague Depopulation and Irrigation Decay in Medieval Egypt

Stuart Borsch

Plague Persistence in Western Europe: A Hypothesis

Ann G. Carmichael

New Science and Old Sources:

Why the Ottoman Experience of Plague Matters

Nükhet Varlık. 
vi CONTENTS

Heterogeneous Immunological Landscapes and

Medieval Plague: An Invitation to a New Dialogue

between Historians and Immunologists

Fabian Crespo and Matthew B. Lawrenz

The Black Death and the Future of the Plague

Michelle Ziegler

Epilogue: A Hypothesis on the East Asian

Beginnings of the Yersinia pestis Polytomy

Robert Hymes 285

\section{FEATURED SOURCE}

Diagnosis of a "Plague" Image: A Digital Cautionary Tale

Monica H. Green, Kathleen Walker-Meikle, and Wolfgang P. Müller 309 


\section{EDITOR'S INTRODUCTION TO PANDEMIC DISEASE INTHE MEDIEVAL WORLD: RETHINKING THE BLACK DEATH}

\section{MONICA H. GREEN}

After The JustinianiC Plague (c. 541-c. 750), which has been called the First Plague Pandemic, the Black Death or Second Plague Pandemic was likely the first semi-global phenomenon that fully merits the name-affecting "all people" (pan + demos). ${ }^{1}$ Total (absolute) mortality would be higher from several nineteenth-century cholera outbreaks, the 1918-19 influenza pandemic, or the current HIV/AIDS pandemic. But when expressed as a percentage of the population, the mortality caused by the Black Death is the highest of any large-scale catastrophe known to humankind, save for the impact of smallpox and measles on indigenous peoples in first-contact events of the early modern period. The Black Death killed an estimated $40 \%$ to $60 \%$ of all people in Europe, the Middle East, and North Africa when it first struck there in the mid-fourteenth century. Its demographic effects are well known (particularly with respect to Western Europe), and there is a considerable body of historical scholarship on population losses and the economic and political changes that ensued. Such questions about its aftermath are important, of course; but so, too, are questions of why and how the pandemic happened in the first place and how it was sustained. For these questions, we currently have no definitive answers. Even its full geographic extent is still unknown: we are only now beginning to engage with scientific and documentary evidence

I On the modern definition of "pandemic," see Morens, Folkers, and Fauci (2004), who identify wide geographic extension, disease movement, high attack rates and explosiveness, minimal population immunity, novelty, infectiousness, contagiousness, and severity as the most commonly used features in describing disease outbreaks as "pandemic". Of these, only contagiousness does not commonly apply to plague since it is normally spread by an arthropod vector, except that pneumonic plague (one of plague's most lethal forms) is directly contagious from person to person. In this essay, I use the term "the Black Death" as synonymous with the Second Plague Pandemic as a whole. Individual contributors to this special issue retain the original usage, applying the term to the first wave of plague that struck the Mediterranean and Western Europe in the mid-fourteenth century. On the issue of plague's chronology and periodization and the definition of "pandemic," see below. 
for plague in East Asia, and we can only suspect (as we will see) whether the disease might have also reached other regions of Afroeurasia as well.

A catastrophe of this magnitude demands explanation. The present collection of essays starts from the premise that studies of the Black Death must embrace a new reality: the fact that the field of microbiology has, in the past two decades, leapt past the barriers of the late nineteenth-century biological laboratory and created new ways to explore the history of pathogenic organisms. Microbiology has effected a transformation in our understanding of the disease's history. It has reconstructed the phylogenetic (evolutionary) history of the plague organism, Yersinia pestis, from modern molecular samples, and it has developed techniques to retrieve and reconstruct genetic material of the pathogen from historical remains. The question "What was the pathogen?" has been decisively resolved. In 2011, over a decade of innovative research (and controversy) in the retrieval and analysis of ancient DNA (aDNA) fragments and other proteins culminated in the reconstruction of the full genome of Yersinia pestis, using the remains of persons buried in London's famed Black Death cemetery (East Smithfield), which can be precisely dated to the first outbreak of plague in London, in 1348-50 (Bos et al. 2011; see also DeWitte 2014 , in this issue). ${ }^{2}$ Even if we cannot yet rule out the possibility that there was more than one organism or other causative factor leading to the mass mortalities in this period, there is no longer any question that $Y$. pestis was a key player.

The essays in this first issue of The Medieval Globe take the new microbiological consensus on the Black Death as a given. Yet the assembled contributors do not contest a key point raised by so-called "plague deniers," who in the past several decades have raised doubts about the role of $Y$. pestis in the pandemic. ${ }^{3}$ Their skepticism arose from the fact that the speed of the disease's spread, and the level of well-documented human mortality it caused during the fourteenth century, in no way match the patterns seen in the Third Plague Pandemic, which is normally dated from around 1894 to the 1930s and during which the foundation was laid for our modern bacteriological and epidemiological understandings of the pathogen and the disease it causes in animals and humans. There is good

2 A superb summary of the developments in microbiology as it relates to historical plagues can be found in Little (2011). The presence of Y. pestis in remains from the time of the Justinianic Plague has now been documented as well. See Green (2014, in this issue) for further details on the contributions of genetics to plague studies.

3 Benedictow (2010) summarizes these perspectives and, in the tenor of his own arguments, reveals how contentious the issue has become. 
reason, now, to question the role that early twentieth-century epidemiology has played in our general constructions of plague's histories, because plague is not always or everywhere the same in its vectors or animal hosts (Royer 2014; see Varlık 2014 and Carmichael 2014, both in this issue). Nevertheless, rather than dismiss the skeptics' focus on the discrepancies between twentieth-century understandings of plague's epidemiology and our medieval evidence, this collection of essays is motivated by an acceptance of the discrepancies. We concede that there is currently no plausible, comprehensive theory that can explain in full detail how the nonmotile, single-celled organism that modern science knows as Yersinia pestis - which may have originated as a new species as little as about 3000 to 4000 years ago (Cui et al. 2013) — could, in an age before steam-powered (let alone jet) travel, have been disseminated across so much of the Eurasian and North African landscape in just a few decades.

Admitting ignorance of the full epidemiological character and amplifying factors of the Second Pandemic does not, however, mean that we have no useful knowledge at all. This may still be terra incognita, but we are not without a compass. Genetic science confirms the very close identity of the strain of the Y. pestis bacillus found in fourteenth-century human remains and the organism as it is found disseminated now throughout most of the inhabited world (Bos et al. 2011; Cui et al. 2013). ${ }^{4}$ The organism itself, therefore, serves as a tracer element, a living chain of evidence that can tie together vastly distant times and places. To borrow a phrase coined by the French historian Emmanuel Le Roy Ladurie (1973), back when the possibilities of modern genetics analysis could barely be fantasized: we have here a "microbial unification of [half] the world." That biological fact enables us to take an interpretative stance: given the same pathogen, more or less the same epidemiological parameters can be inferred in terms of necessary environmental conditions, modes of transmission, and symptomatologies in infected hosts. We may not yet know all the species of arthropod vectors or mammalian hosts we need to search out; we may not yet know all the climatic and other environmental factors that contributed to the propagation of $Y$. pestis. We certainly do not know

4 Ancient DNA (aDNA) retrieved from the period of the Justinianic Plague also fits into phylogenetic understandings that have already been postulated for the evolution of $Y$. pestis since its divergence from its most recent common ancestor; see Harbeck et al. 2013 and Wagner et al. 2014. On the dissemination of Y. pestis in the Third Pandemic, see Morelli et al. 2010. Plague foci currently exist in North and South America, Africa, and Eurasia. Although plague reached Australia in 1900, it does not seem to have established permanent foci there; see Curson and McCracken 1989. 
all the human factors of trade in grains or textiles or other material goods and foodstuffs that created the microenvironments allowing Y. pestis to spread. But we do know that we need to search out those connections.

Accepting the precepts of an evolutionary perspective on the history of $Y$. pestis suggests that the field of historical plague studies as it relates to the Second Pandemic must be redefined in three dimensions: its geographic extent, its chronological extent, and the methodological registers we use to investigate it. The essays in this volume pursue, from various perspectives, all these agendas.

First, the geography of the Second Pandemic must be expanded. Black Death studies can no longer be defined as if the disease struck only Western and Central Europe, as is often depicted in maps, sourcebooks, and textbooks. ${ }^{5}$ Analyses of the evolutionary history of $Y$. pestis from modern samples have suggested since 2004 that the geographic origins of the pathogen were likely on the Tibetan-Qinghai Plateau (Achtman et al. 2004). ${ }^{6}$ Y. pestis had to move across as many animal species (arthropod vectors as well as mammalian hosts) as climatic zones in order to cause the massive mortality in human bodies that it did in the fourteenth century (and episodically thereafter). But again, the microbiology makes clear that it did move. Contributors to this volume cover geographic terrain from China to all sides of the Mediterranean and on to England. In my own essay, I suggest that even the Indian Ocean basin merits exploration as a route possibly as important as the Silk Roads; at least, that is a possibility worth exploring given that genetics research ties sub-Saharan Africa to our premodern plague narratives. The call for an expanded geography also includes calling for a veritable menagerie of possible hosts for the organism. Y. pestis always needs precise microenvironments to thrive and even more precise circumstances of transfer across species to create human plague. But limiting plague's narrative to one or two kinds of rats and fleas occludes too much: it defies the evidence that modern entomology and zoology have brought forward, which reminds us repeatedly that human plague is a relatively rare epiphenomenon in Y. pestis's evolution. Although humans have regularly been involved in plague's long-distance spread, Yersinia pestis survives because it establishes itself in microenvironments that more or less replicate those of its origin. Marmots and gerbils (and guinea pigs and prairie dogs) are more important for that long-term survival than rats.

5 Even for Europe, such maps pose major interpretative problems (Mengel 2011).

6 A summary of debates on the geographic origin of $Y$. pestis can be found in Green (2014, in this issue); see also Hymes (2014, in this issue). 
Second, the chronology of the Black Death must be expanded. ${ }^{7}$ The term "Black Death" has often been used to denote just the first "wave" of plague that struck the Mediterranean and Western Europe between 1347 and 1353. Usage of the term in that narrow sense is still justified, especially when examining many kinds of synchronous sources at the period of the highest collective human mortality. However, beyond its Eurocentricity, the narrow time frame beginning in 1347-or 1346, if we include the outbreak in Kaffa, where besieging Mongols are famously said to have hurled infected bodies over the city walls-obscures two epidemiological facts that must be addressed: first, that plague came to Kaffa from somewhere; and second, that plague did not simply come to Western Eurasia, it stayed. How much earlier than 1346/7 we must look for the "origin" of the Black Death is not yet clear. In 2013, microbiologists Cui and colleagues proposed a polytomy, a sudden divergence or "Big Bang" of $Y$. pestis into four new lineages, likely caused because it was moving into new host species (Cui et al. 2013). They suggested a median date of c. 1268 with a 95\% confidence interval of 1142-1339. As Robert Hymes suggests in his epilogue to this collection, "A Hypothesis on the East Asian Beginnings of the Yersinia pestis Polytomy," Cui and colleagues' proposed dating coincides intriguingly with events taking place in the first decades of the thirteenth century near the edge of the Tibetan-Qinghai Plateau-events that might possibly serve as the "disseminating factor" necessary to start the process of $Y$. pestis's spread to other environments. The possible role of climatic change in catalyzing the thirteenth-century polytomy, or, indeed, in any other major outbreak of plague, has not yet been defined decisively, but evidence is increasingly suggesting that though small localized outbreaks of plague occur regularly wherever it has established enzootic foci, the commonality of more widespread outbreaks is due to climatic factors. ${ }^{8}$

7 This issue of chronological definition was addressed by Little (2011: 271): "the Black Death [is] a name that many historians restrict to the massive mortality throughout Europe between 1347 and 1353 but is better understood as a pandemic that began in Central Asia in the 1330s, subsequently spread through Europe and the Middle East starting in the late 1340s, and made frequent returns in those regions for over four centuries." And just as this issue argues for extending the Second Plague Pandemic forward into the nineteenth century, arguments are also being made to extend the Third Pandemic back into the eighteenth century; a beginning date of $c .1772$ is implied by Benedict (1996) and taken as the foundation for research in Xu et al. (2014).

8 On the correlation of climate with widespread outbreaks, as established by modern observational science and predictions about what current climate change might do to plague dynamics in the future, see, e.g., Stenseth et al. 2006; Ben Ari et al. 2011; and Gage 2012. In-progress work by Bruce Campbell (2013) suggests that major climatic 
As for the end date of the Second Pandemic, we clearly must look well beyond 1353. For Western Europe, we have long known that plague outbreaks continued to occur up through the early eighteenth century, but even such oft-cited dates as 1679 (for the last plague outbreak in England) and 1722 (for the Continent, following the last major outbreak in Marseille, 1720) may be illusory (Cummins, Kelly, and Ó Gráda 2013; Ermus 2014). If, moreover, we add in the Islamicate world, the 1722 end date for the Second Pandemic becomes meaningless. Outbreaks in North Africa, the Ottoman empire, and even Russia certainly continued well into the nineteenth century (Varlık 2014, in this issue; Mikhail 2012; Robarts 2010). Were all these outbreaks repeated importations from enzootic loci "elsewhere"? Or do they reflect local cases of plague persistence? Because we currently lack any aDNA from sites in Central Eurasia, we cannot settle these questions now. For example, a strain of $Y$. pestis recently documented in Libya comes from Branch 2 of the general phylogenetic tree, which diverged from Branch 1, the lineage involved in both the Black Death (as documented from London remains) and the global Third Pandemic; this divergence occurred some seven hundred to eight hundred years ago (Cui et al. 2013). Since strains from Branch 1 are also documented in other parts of North Africa, the Libyan case suggests that we may well be looking at the remnants of more than one pandemic leaving its traces in that region (Cabanel et al. 2013). There may, in other words, have been multiple amplifications of $Y$. pestis in the late medieval and early modern periods that have left living descendants to this day. Can we really say that the Second Plague Pandemic ever ended?

Third, it is now obligatory that plague studies be broadened into a multidisciplinary mode. There is no single discipline or investigative approach that can be privileged: microbiologists may study the evolution or particular genetic characteristics of the pathogen, but that single-celled organism only creates "plague" when it passes through various environments, different hosts as well as different ecosystems. Entomologists must study the arthropod vectors, zoologists must study the many different possible mammalian hosts for the disease, from the tiniest rodents up through carnivores and camels. Bioarcheologists are the guardians of all aspects of retrieval, classification, and analysis of material remains, not only of humans and their artifacts but also all the species that form

changes occurred throughout the northern hemisphere in the early 1340s, which may have been a particular precipitating factor for the events that pushed plague into the Black Sea and Mediterranean basins. On climate and the Justinianic Plague, see Green 2014 , in this issue. 
the chains through which $Y$. pestis passes. And finally, humanists-historians, but also linguists and art historians and others who painstakingly interpret the cultural products of human societies-are needed to reconstruct not only the ways in which humans contributed to the creation of conditions ripe for amplification of $Y$. pestis on pandemic scales, but also the many human responses to plague and catastrophic mortality, be they medical or religious, palliative or murderous.

The following essays attempt to lay out a forward path for studies of plague in this multidisciplinary and collaborative mode. In the opening essay, "Taking 'Pandemic' Seriously: Making the Black Death Global," I ask what the implications are for our histories of the Black Death when we take into account the major transformations in the biological sciences during the past fifteen years. I argue that approaching plague studies from the perspective of global health history allows the creation of frameworks of analysis that are both richly multidisciplinary and productive of new research agendas. The field of global history writ large is already known for embracing broad expanses of both time and place, literally covering the globe but also (in its mode as Deep History) going back to the time of human origins - and, in some cases, beyond. Global history is also generally quite interdisciplinary, recognizing that narratives at those levels of scale cannot rely solely on written documentation. But with different sources and methods come different research goals. What the microbiologist or historical epidemiologist wants to explain is different from what the historian of religious persecution or public health seeks to document. A major obstacle to fruitful dialogue between the humanistic and scientific approaches has been historians' aversion to agendas that smacked of "retrospective diagnosis": the imposition of modern categories of scientific disease classification on evidence from the past; this aversion has been especially strong among recent generations of historians of medicine. My essay suggests that using the categories of modern science to reconstruct plague's histories-adopting an outsider's (etic) perspective on the material history of plague-is actually essential to reconstructing the history of participants' experiences of those material conditions and the resulting experiences of sudden death, economic devastation, and social chaos (an emic perspective). Both are valid, and both are necessary to a historical enterprise that unites the efforts of scientists and humanists alike.

As has been noted, the common practices of long-distance trade or animal husbandry that facilitated the spread of $Y$. pestis to lands far distant from the Tibetan-Qinghai Plateau are yet to be discovered. But spread it did, and it is certain that human activities, unwitting though they may have been, were responsible. Epidemiologically, we would now "blame" 
the grain distributor or the trader in furs or the second-hand clothes dealer for creating mobile microenvironments that facilitated the spread of $Y$. pestis. But these causes would not have been apparent to medieval actors, and it has long been known that, in their terror, people in the fourteenth century looked in many directions to answer the question "Why?" In Christian Europe, reproachful eyes often turned toward resident Jewish communities. ${ }^{9}$ In "The Black Death and its Consequences for the Jewish Community in Tàrrega: Lessons from History and Archeology," Anna Colet, Josep Xavier Muntané i Santiveri, Jordi Ruíz Ventura, Oriol Saula, M. Eulàlia Subirà de Galdàcano, and Clara Jáuregui unite an emic approach to the perspectives of historical human actors with the etic approach implicit in archeology's reconstruction of material culture. Beginning in 2007, excavations were undertaken on the Maset hill in a suburb of the Catalonian town of Tàrrega: a site subsequently identified as that of the town's medieval Jewish cemetery. Analysis of the human remains found in several communal graves (a burial practice rare among medieval Jews) shows that many had suffered a violent death. Linking this material evidence to written documentation of attacks against the Jewish community of Tàrrega in July 1348, Colet and her colleagues find astonishing parallels between two very different kinds of evidence. Arriving in the port of Barcelona, the plague had spread inland to Cervera and then to Tàrrega. And immediately on the heels of the plague spread waves of hate, according to official records kept by the Crown of Aragon, which reports that twenty Jews were killed in Barcelona, eighteen in Cervera, and three hundred in Tàrrega. This contemporary record of mass murder in Tàrrega, one of the earliest to be associated with the plague's arrival on the European mainland in the spring of 1348, is now confirmed by the archaeological evidence published here. This evidence corroborates not only violent deaths and the postmortem desecration of some bodies, but also the careful attempts, probably by the community's surviving Jews, to give the deceased a ritually appropriate burial.

Archeology takes us in a very different direction in Sharon DeWitte's contribution, "The Anthropology of Plague: Insights from Bioarcheological Analyses of Epidemic Cemeteries." Bioarcheology is a relatively recent designation for archeological work that encompasses paleopathology (the determination of disease or nutritional deficits from human remains) and combines it with fuller contextual analysis to create a rich understanding

9 It has long been recognized that minority Jewish communities were not targeted in the Islamic regions of the medieval world (Dols 1974). On the varied attempts to explain the contagion, see Stearns 2011. 
of how whole communities lived (and died). As recently as a decade ago, it was believed that plague was one of the diseases that bioarcheology could not reconstruct. The "osteological paradox" holds that bone only reacts slowly to most stressors. Whereas violent trauma (as in the case of the Tàrrega victims) will immediately create lesions in bone, disease or nutritional deficits take time to work their destructive effects. Hence, anything that kills quickly (like plague, which can strike a human down in anywhere from two to ten days) does not have time to damage the bone in any discernible way. Now, of course, bioarcheology is at the forefront of historical plague studies, not simply because $Y$. pestis aDNA can be extracted from teeth excavated by archeologists, but because new innovative techniques of epidemiological analysis at the population level allows us to assess the health state of victims, and also the cultural attitudes and responses toward mass mortality as evidenced in burial practices themselves. Excavations of mass gravesites in London have been particularly revelatory because the sites can be precisely dated and contextualized from supporting documentary information. DeWitte's summary of current research (much of it her own) also allows us to see some of the directions in which multidisciplinary work on plague and other epidemic diseases will take us in the future.

In his essay, "Plague Depopulation and Irrigation Decay in Medieval Egypt," Stuart Borsch examines plague depopulation's very direct effect on the economic infrastructure of Egypt in the late medieval period. Several essays in this volume focus on the ecologies that facilitate plague maintenance, amplification, or transmission. Borsch, in contrast, reminds us that plague can create a new ecology for humans. By eliminating human actors whose agricultural practices had regulated the environment, plague literally transformed the landscape of Egypt. Irrigation systems and the social and technological institutions that had built them up over many millennia fell into ruin because major population losses, caused by recurrent outbreaks of plague, severely circumscribed the amount of labor available to maintain this elaborate infrastructure, designed to control and exploit the flooding of the Nile River. By 1468, Egyptian officials themselves could not explain why their predictions for the annual flood had failed for the first time since records began to be kept, in the third millennium BCE. The magnitude of mortality from plague, which seems to have been far more extreme than can be documented for other disease pandemics, is likely the key factor in Egypt's drastic economic decline.

In her essay "Plague Persistence in Western Europe: A Hypothesis," Ann G. Carmichael explores an issue hinted at in Borsch's account of recurrent plague in Egypt. Although we do not know the precise mechanisms of its 
spread, there is little reason at this point to doubt medieval reports that the "great mortality" in Western Europe and North Africa came via ships, arriving first in the seaports of the Mediterranean and then at other ports on the Atlantic and North Sea coasts. But our modern knowledge of Y. pestis - drawn from studies of sylvatic (or "maintenance") foci of the organism in North and South America, Africa, and Asia-shows that Y. pestis can be readily established in rodent communities within a few years of its introduction to a new geographic area. Often, those new foci are established at high elevations. ${ }^{10}$ Carmichael raises the question of whether the Alps became one such area where local foci were established in Europe, causing recurrent plague outbreaks in the early modern period. That is, documented waves of the plague in later centuries came, not through reintroductions of the organism via long-distance trade networks linked to Central Asia (though that may also have happened), but from Northern Europe's own sylvatic foci in local mountainous areas. Beginning her narrative with a handful of deaths in small mountain villages in 1567, Carmichael moves both forward and backward in time, ending with the second wave of the epidemic in Western Europe, that of 1359-63. As was noted at the time, this epidemic moved down from upland communities into metropolitan centers such as Milan, not from coastal cities into the interior; this was the mortality so famously recorded and bemoaned by the poet Francesco Petrarca (d. 1374), who had already lost his beloved Laura to the Black Death in 1348, and who was now to lose his son and a good friend in this new epidemic. In order to lay out this hypothesis (itself a wonderful example of how the new science of plague can stimulate new research questions for historians), Carmichael is impelled to raise questions about what animal species may have served as local hosts for Y. pestis. The fact that the European Alps, like the Tibetan-Qinghai Plateau, had a resident species of marmot is, she suggests, likely one part of the answer to how plague came to persist in late medieval and early modern Western Europe.

Like Borsch and Carmichael, Nükhet Varlık shows how command of what she calls "local knowledge" can, when set into larger frameworks of epidemiological and scientific analysis, yield results that enlighten not only contemporaries' experiences of plague in one part of the world, but our larger understanding of plague's causes and effects. In her essay "New Science and Old Sources: Why the Ottoman Experience of Plague Matters,"

I 0 This phenomenon has been noted for individual localities but has not been studied systematically, so far as I have been able to determine. See, for example, Eisen et al. 2010; Neerinckx et al. 2010; MacMillan et al. 2011; Eisen et al. 2012; Andrianaivoarimanana et al. 2013; and Schneider et al. 2014. 
Varlık begins by noting that Eurocentric narratives of plague history have rendered invisible the geographic and temporal extent of plague-and, thus, human experiences of the disease-in other areas of the Eurasian world. While the Second Pandemic may have started at approximately the same time in Western Europe and in the lands that would later form the Ottoman empire, outbreaks of plague continued in Ottoman territories well into the nineteenth century, far beyond the chronological parameters that have been established with reference to European cases alone. Like Carmichael, Varlık explores the historical importance of determining whether plague established urban or rural foci, allowing Y. pestis to perpetuate itself independently of newly imported infections. And like Green and Carmichael, Varlık stresses the importance of adopting more complex models of plague-transmission, models which pay special attention to interspecies dynamics. Importantly, Varlık also gives us a lesson in seeing science itself as dynamic. Although the contributors to this special issue regularly rely on scientific claims about $Y$. pestis's evolution or ecology or physiological effects, we recognize that this body of knowledge is ever changing. Just as the universalist claims of science must be made locally specific in the hands of the well-trained historian, so too must the scientific understandings of the past be recognized as the products of culturally specific moments. Varlık suggests the need to re-examine the ways that some basic tenets of plague science were formulated in the early twentieth century. "These imagined divisions of epidemiological experience," she says, "have resulted in separate histories of plague in Europe and the Middle East/Islamic world" (Varlık 2014, in this issue, p. 205).

Recognizing that plague remained a repeated threat in many communities into the nineteenth century-and remains a threat today for those human populations living around established plague foci-Fabian Crespo and Matthew B. Lawrenz bring the perspectives of biological anthropology and microbiology to bear in their essay "Heterogeneous Immunological Landscapes and Medieval Plague: An Invitation to a New Dialogue between Historians and Immunologists." Modern scientific understanding of mammalian immune systems has been transformed in the past four decades, in part because the HIV/AIDS pandemic made such knowledge desperately urgent. Certain misunderstandings of immunity have been widespread in discussions about historical plague, among them the misleading idea that whole populations can suddenly and permanently "acquire" immunity to certain pathogens if a part of that population survives an epidemic event. Crespo and Lawrenz are concerned, rather, to lay the foundation for experimental investigation of whether any immunological characteristics (innate and acquired) already present in Western Europe's diverse gene 
pool and ecology may have acted differentially in facilitating the survival of some exposed individuals rather than others. Just as DeWitte finds evidence for differential survival based on an individual's prior exposure to compromised nutrition or other stressors, Crespo and Lawrenz wish to explore from an immunological perspective the basic question of differential survival that is the foundation of all epidemiological investigation. Crespo and Lawrenz's articulation of these questions shows how fruitful dialogue between the many historicist disciplines can be. As they note, "historians must step in and help scientists put all these biological differences into context."

Our next essay, "The Black Death and the Future of the Plague," written by Michelle Ziegler, a microbiologist and specialist in disaster preparedness, considers the reasons why this most "medieval" of diseases remains of urgent concern today. As noted above, much of our modern understanding of plague's human epidemiology comes from studies made during the Third Plague Pandemic in the late nineteenth and early twentieth centuries: right at the time when germ theory was establishing a new paradigm for understandings of disease. Current scientific concerns are related not simply to fears of biological warfare (already attempted earlier in twentieth century) but also to threats of disease re-emergence and antibiotic resistance, threats that have only become fully apparent since the 1990s. The complete reconstruction of the genome of $Y$. pestis from fourteenthcentury samples shows that the organism as it existed then is not radically different from the organism that exists in numerous strains throughout the world in the present day. In other words, in terms of the pathogenicity or virulence of the organism (and, probably, human susceptibility to it), the Black Death could happen all over again today, given the proper conditions. That raw fact is what propels millions of dollars of new research on $Y$. pestis. The medieval Black Death, therefore, is far more than a mere historical curiosity; it is, in all its complexity, the source of vital data that can help us to establish scenarios for pandemic disease now and in the future.

Late in the process of assembling this collection, we had the good fortune to be put in touch with Robert Hymes, a historian of China whose epilogue now rounds out our narrative. While Ziegler brings the Black Death's narratives into the twenty-first century, Hymes takes us back to its beginning-or, at least, the beginning as currently hypothesized by genetics science. Hymes offers a tentative rereading of Chinese historical sources from the thirteenth century, more than a century before plague arrived in the Mediterranean basin. Historiography on China has long been reluctant to see plague as a factor in East Asian history, where references to epidemics are abundant but descriptions of what could be inter- 
preted specifically as "plague" are exiguous: even the recent publication of major genetics studies asserting an Asian origin of $Y$. pestis did not shake the fundamental skepticism of those who maintain that human plague was not a major factor in China's medieval history (Buell 2012). Hymes, however, takes the sudden divergence of $Y$. pestis postulated by genetics in 2013 (the polytomy mentioned above, estimated to have occurred between the twelfth and early fourteenth centuries) as an invitation to begin assembling several pieces of a scattered puzzle: the sequence of Mongol raids against towns on the northern border of the Tibet-Qinghai plateau starting in the 1210s; the reports that the Mongols themselves were experiencing unaccustomed illness on these campaigns; reports of epidemics in major cities, and so forth. He calls for a new reading of the Chinese sources from the period, one more sensitive to the claims that they themselves are making: including the claim that contemporaries were witnessing an epidemic that appears to have been new in its manifestations. Although Hymes's study is, like Carmichael's, presented as a hypothesis, the interpretative power of both essays comes from taking the historical sources as seriously as the science. Such meticulous scholarship has the potential to recreate, at a level of detail never before imaginable, the paths that different strains of $Y$. pestis might have taken as they reshaped the populations and landscapes of Eurasia.

Finally, in the interests of making new historical documentation available-and to allow students to see for themselves how historians craft understandings of the past-we offer a "featured source": "Diagnosis of a 'Plague' Image: A Digital Cautionary Tale." This essay returns us to London, the site of the Black Death cemetery at East Smithfield whence the Yersinia pestis genome was retrieved in 2011. Much of the work that geneticists have done in the past fifteen years has been premised on dramatic advances in computerization, which allow manipulation of many terabytes of genetic data simultaneously. For the humanities, computerization, and specifically the Internet, has made possible the wide dissemination of texts and images. That such new freedom should generate errors, too, is to be expected. The surprise lies in what we found while correcting the error of a "misdiagnosed" image of "plague" using appropriate humanistic analysis of its manuscript context and situated meaning: we were soberingly reminded that plague was not the only disease that troubled people in the middle of the fourteenth century. Although science plays no role in this analysis, I and my coauthors-historian of medicine Kathleen Walker-Meikle and canon law specialist Wolfgang P. Müllerhappily acknowledge our debt to scientists who for many decades have been modeling the benefits of collaborative work. 
This volume, the inaugural issue of The Medieval Globe, is put forward in the belief that dialogue between historical records and modern science, between quantifiable assessment of material remains and the intangibles of humanistic method, is not an exercise in presentism but an opportunity to take seriously the task of reconstructing the world that historical actors inhabited, right down to the microbes that killed them. In an earlier draft of her essay, Ann Carmichael quoted the environmental historian Richard C. Hoffman, who observed that we are dealing with events that "took place before we were in a position to see [them]" (Hoffman 1995: 59). We are in a position to see so much more now-from both emic and etic perspectives-and what we see is an enlarged, more dynamic, and more complex medieval globe.

\section{Acknowledgments}

I and all the contributors to this volume collectively owe thanks to several groups of people and institutions for making this work possible. Nine years ago at Arizona State University, I discovered in the Bioarcheology Program colleagues (most importantly, Jane Buikstra) whose professionalism and driving curiosity about disease experiences in the past have set the standard for the work I aspire to here. That enthusiasm was transferred for two wonderful summers to London, where the Wellcome Library hosted my National Endowment for the Humanities Summer Seminars; the participants there were the first to wrestle with the problem of opening up dialogue between the humanities and the historicist sciences on the huge question of plague's history. We owe a special debt of gratitude to Jelena Bekvalac and Rebecca Redfern of the Human Bioarchaeology Centre at the Museum of London for allowing us to examine their collections from the London Black Death Cemetery, and to Rachel E. Scott (now of DePaul University) who was our bioarcheological guide. In 2012, Michelle Ziegler created the Plague Working Group, an invaluable small community for discussing the latest work in the field. In 2013-14, the Institute for Advanced Study at Princeton provided me with an incomparable cohort of historians from across the chronological and geographic range, together with intellectual sustenance of every other kind; funding while at the Institute was provided by the National Endowment for the Humanities and the Willis F. Doney Membership Endowment.

The particular debt we owe collectively is to the World History Center of the University of Pittsburgh. By granting me an appointment as Visiting Scholar in 2013-14, the Center provided not simply another welcoming audience but also funds to subsidize conference travel critical to this project and, most importantly, to underwrite the open-access publication of this volume. None of these individuals or institutions bears responsibility for statements made in this or the following essays, though I hope all will recognize with pride their essential contributions. Any views, findings, conclusions, or recommendations expressed in this publication do not necessarily reflect those of the National Endowment for the Humanities. 
Finally, we thank Carol Symes, founding editor of The Medieval Globe, for her belief that the Black Death could provide a valuable exploratory path between and beyond traditional geographic and disciplinary boundaries, and for investing extraordinary levels of patience and care in editing this issue.

\section{Bibliography}

Achtman, M., G. Morelli, P. Zhu, T. Wirth, et al. 2004. "Microevolution and History of the Plague Bacillus, Yersinia pestis," Proceedings of the National Academy of Sciences 101, no. 51: 17837-42

Andrianaivoarimanana, V., K. Kreppel, N. Elissa, J.-M. Duplantier, et al. 2013. "Understanding the Persistence of Plague Foci in Madagascar," PLoS Neglected Tropical Diseases 7, no. 11: e0002382

Ben Ari, T., S. Neerinckx, K. L. Gage, K. Kreppel, et al. 2011. "Plague and Climate: Scales Matter," PLoS Pathogens 7, no. 9: e1002160

Benedict, Carol. 1996. Bubonic Plague in Nineteenth-Century China (Stanford: Stanford University Press)

Benedictow, Ole. 2010. What Disease was Plague? On the Controversy over the Microbiological Identity of Plague Epidemics of the Past (Leiden: Brill)

Borsch, Stuart. 2014. "Plague Depopulation and Irrigation Decay in Medieval Egypt," The Medieval Globe 1: 125-156

Bos, K. I., V. J. Schuenemann, G. B. Golding, H. A. Burbano, et al. 2011. "A Draft Genome of Yersinia pestis from Victims of the Black Death," Nature 478, no. 7370: 506-10

Buell, Paul D. 2012. "Qubilai and the Rats," Sudhoffs Archiv 96: 127-44

Cabanel, N., A. Leclercq, V. Chenal-Francisque, B. Annajar, et al. 2013. "Plague Outbreak in Libya, 2009, Unrelated to Plague in Algeria," Emerging Infectious Diseases 19, no. 2: 230-36

Campbell, Bruce M. S. 2013. "The Great Transition: Climate, Disease and Society in the 13th and 14th Centuries," The Ellen McArthur Lectures, University of Cambridge < http://www.econsoc.hist.cam.ac.uk/podcast-campbell.html> [accessed January 9, 2014]

Carmichael, Ann G. 2014. "Plague Persistence in Western Europe: A Hypothesis," The Medieval Globe 1: 157-191

Colet, Anna, Josep Xavier Muntané i Santiveri, Jordi Ruíz Ventura, Oriol Saula, et al. 2014. "The Black Death and its Consequences for the Jewish Community in Tàrrega: Lessons from History and Archeology," The Medieval Globe 1: 63-96 Crespo, Fabian, and Matthew B. Lawrenz. 2014. "Heterogeneous Immunological Landscape and Medieval Plague: An Invitation to a New Dialogue between Historians and Immunologists," The Medieval Globe 1: 229-258

Cui, Y., C. Yu, Y. Yan, D. Li, et al. 2013. "Historical Variations in Mutation Rate in an Epidemic Pathogen, Yersinia pestis," Proceedings of the National Academy of Science 110, no. 2: 577-82 
Cummins, Neil, Morgan Kelly, and Cormac Ó Gráda. 2013. "Living Standards and Plague in London, 1560-1665," Social Science Research Network <http:// ssrn.com/abstract=2289094> [accessed September 10, 2014]

Curson, P. H., and K. McCracken. 1989. Plague in Sydney: The Anatomy of an Epidemic (Kensington: New South Wales University Press)

DeWitte, Sharon N. 2014. "The Anthropology of Plague: Insights from Bioarcheological Analyses of Epidemic Cemeteries," The Medieval Globe 1: 97-123

Dols, Michael. 1974. "The Comparative Communal Responses to the Black Death in Muslim and Christian Societies," Viator 5: 269-87

Eisen, R. J., K. S. Griffith, J. N. Borchert, K. MacMillan, et al. 2010. "Assessing Human Risk of Exposure to Plague Bacteria in Northwestern Uganda Based on Remotely Sensed Predictors," American Journal of Tropical Medicine and Hygiene 82, no. 5: 904-11

Eisen, R. J., J. N. Borchert, J. T. Mpanga, L. A. Atiku, et al. 2012. "Flea Diversity as an Element for Persistence of Plague Bacteria in an East African Plague Focus," PLoS ONE 7, no. 4: e3559

Ermus, Cindy. 2014. "Pestilence and Politics: A Global History of the Marseille Plague" (PhD dissertation, Florida State University)

Gage, K. L. 2012. "Factors Affecting the Spread and Maintenance of Plague," in Advances in Yersinia Research, ed. Alzira Maria Paiva de Almeida and Nilma Cintra Leal, special issue, Advances in Experimental Medicine and Biology 954, no. 1: 79-94

Green, Monica H. 2014. "Taking 'Pandemic' Seriously: Making the Black Death Global," The Medieval Globe 1: 27-61

Harbeck, M., L. Seifert, S. Hänsch, D. M. Wagner, et al. 2013. "Yersinia pestis DNA from Skeletal Remains from the 6th Century AD Reveals Insights into Justinianic Plague," PLoS Pathogens 9, no. 5: e1003349

Hoffman, R. C. 1995. "Environmental Change and the Culture of Common Carp in Medieval Europe," Guelf Ichthyology Review 3, no. 1: 57-85

Hymes, Robert. 2014. "A Hypothesis on the East Asian Beginnings of the Yersinia pestis Polytomy," The Medieval Globe 1: 285-308

Le Roy Ladurie, Emmanuel. 1973. “Un concept: l'unification microbienne du monde (XVIe-XVIIe siècles)," Schweizerische Zeitschrift für Geschichte 23, no. 4: 627-96 (An abbreviated English translation is also available: Emmanuel Le Roy Ladurie. 1981. "A Concept: The Unification of the Globe by Disease," trans. Sian Reynolds and Ben Reynolds, in The Mind and Method of the Historian, 28-83 (London: Harvester))

Little, Lester K. 2011. "Plague Historians in Lab Coats," Past and Present 213: 267-90

MacMillan, K., R. E. Enscore, A. Ogen-Odoi, J. N. Borchert, et al. 2011. "Landscape and Residential Variables Associated with Plague-Endemic Villages in the West Nile Region of Uganda," American Journal of Tropical Medicine and Hygiene 84, no. 3: 435-42

Mengel, David. 2011. "A Plague on Bohemia? Mapping the Black Death," Past and Present 211: 3-34 
Mikhail, Alan. 2012. "Plague and Environment in Late Ottoman Egypt," in Water on Sand: Environmental Histories of the Middle East and North Africa, ed. Alan Mikhail, 111-32 (Oxford: Oxford University Press)

Morelli, G., Y. Song, C. J. Mazzoni, M. Eppinger, et al. 2010. “Yersinia pestis Genome Sequencing Identifies Patterns of Global Phylogenetic Diversity," Nature Genetics 42, no. 12: 1140-45

Morens, D. M., G. K. Folkers, and A. S. Fauci. 2009. "What Is a Pandemic?," Journal of Infectious Diseases 200, no. 7: 1018-21

Neerinckx, S., A. Townsend Peterson, H. Gulinck, J. Deckers, et al. 2010. "Predicting Potential Risk Areas of Human Plague for the Western Usambara Mountains, Lushoto District, Tanzania," American Journal of Tropical Medicine and Hygiene 82, no. 3: 492-500

Robarts, Andrew. 2010. "A Plague on Both Houses? Population Movements and the Spread of Disease across the Ottoman-Russian Black Sea Frontier, 1768-1830s" (PhD dissertation, Georgetown University)

Royer, Katherine. 2014. "The Blind Men and the Elephant: Imperial Medicine, Medieval Historians, and the Role of Rats in the Historiography of Plague," in Medicine and Colonialism: Historical Perspectives in India and South Africa, ed. Poonam Bala, 99-110 (London: Pickering \& Chatto)

Schneider, M. C., P. Najera, S. Aldighieri, D. I. Galan, et al. 2014. "Where Does Human Plague Still Persist in Latin America?," PLoS Neglected Tropical Diseases 8, no. 2: e2680

Stearns, Justin K. 2011. Infectious Ideas: Contagion in Premodern Islamic and Christian Thought in the Western Mediterranean (Baltimore: Johns Hopkins University Press)

Stenseth, N. Chr., N. I. Samia, H. Viljugrein, K. L. Kausrud, et al. 2006. "Plague Dynamics are Driven by Climate Variation," Proceedings of the National Academy of Sciences 103, no. 35: 13110-15

Varlık, Nükhet. 2014. "New Science and Old Sources: Why the Ottoman Experience of Plague Matters," The Medieval Globe 1: 193-227

Wagner, D. M., J. Klunk, M. Harbeck, A. Devault, et al. 2014. "Yersinia pestis and the Plague of Justinian, 541-543 AD: A Genomic Analysis," Lancet Infectious Diseases 14, no. 4: 319-26

Xu, L., L. Chr. Stige, K. L. Kausrud, T. Ben Ari, et al. 2014. "Wet Climate and Transportation Routes Accelerate Spread of Human Plague," Proceedings of the Royal Society B: Biological Sciences 281, no. 1780: 20133159

Ziegler, Michelle. 2014. "The Black Death and the Future of the Plague," The Medieval Globe 1: 259-284 
Monica H. Green (Monica.Green@asu.edu) is a historian of medieval European medicine and global health. In 2009 and 2012, she ran a National Endowment for the Humanities Summer Seminar in London on "Health and Disease in the Middle Ages," which had as its central goal the exploration of ways that the scientific and humanistic disciplines could engage in productive dialogue about the history of disease and health-seeking behaviors. During this same period, she has also argued for the development of a new field, "Global History of Health," which explores the evolution of the major pathogens that have afflicted the human species since its origin up to the present day, and the ways that human cultural changes have facilitated or hindered those pathogens' trajectories. In addition to many works on the cultural history of medieval medicine, she is the author of "The Value of Historical Perspective," in The Ashgate Research Companion to the Globalization of Health, ed. Ted Schrecker (Aldershot: Ashgate, 2012), pp. 17-37; and "The Globalisations of Disease," which will be published in 2015.

Abstract Extraction of the genetic material of the causative organism of plague, Yersinia pestis, from the remains of persons who died during the Black Death has confirmed that pathogen's role in one of the largest pandemics of human history. This then opens up historical research to investigations based on modern science, which has studied Yersinia pestis from a variety of perspectives, most importantly its evolutionary history and its complex ecology of transmission. The contributors to this special issue argue for the benefits of a multidisciplinary and collaborative approach to the many remaining mysteries associated with the plague's geographical extent, rapid transmission, deadly outcomes, and persistence.

Keywords Yersinia pestis, Second Plague Pandemic, Afroeurasia, anti-Jewish violence, bioarcheology, biological anthropology, microbiology, historical method. 


\section{THE MEDIEVAL GLOBE}

The Medieval Globe provides an interdisciplinary forum for scholars of all world areas by focusing on convergence, movement, and interdependence. Contributions to a global understanding of the medieval period (broadly defined) need not encompass the globe in any territorial sense. Rather, $T M G$ advances a new theory and praxis of medieval studies by bringing into view phenomena that have been rendered practically or conceptually invisible by anachronistic boundaries, categories, and expectations. TMG also broadens discussion of the ways that medieval processes inform the global present and shape visions of the future.

Submissions are invited for future issues. Please contact the Editorial Board (medievalglobe@illinois.edu). All articles will be evaluated by the editors and by a double-blind peer review process. For more information about $T M G$, with further details about submissions and peer review policy, please visit the journal's website: www.arc-humanities.org/the-medieval-globe.html.

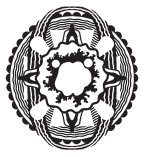

The mark of The Medieval Globe was designed by Matthew Peterson and draws on elements derived from six different medieval world maps.

\section{Executive Editor}

Carol Symes, University of Illinois at Urbana-Champaign

\section{Editorial Board}

James Barrett, University of Cambridge

Kathleen Davis, University of Rhode Island

Felipe Fernández-Armesto, University of Notre Dame

Elizabeth Lambourn, De Montfort University

Yuen-Gen Liang, Wheaton College

Victor Lieberman, University of Michigan at Ann Arbor

Carla Nappi, University of British Columbia

Elizabeth Oyler, University of Illinois at Urbana-Champaign

Christian Raffensperger, Wittenberg University

Rein Raud, University of Helsinki \& Tallinn University

D. Fairchild Ruggles, University of Illinois at Urbana-Champaign

Alicia Walker, Bryn Mawr College 